\title{
Perbandingan Penurunan Tekanan Darah Pasien Hipertensi Intradialisis dengan Obat Antihipertensi Amlodipin dan Kaptopril di RS Bhayangkara Tk. I R. Said Sukanto
}

\author{
Mazaya, S.S. ${ }^{1}$, Rifkia, V. ${ }^{2 *}$, Chairani, A. ${ }^{3}$ \\ ${ }^{1}$ Program Sarjana Fakultas Kedokteran Universitas Pembangunan Nasional Veteran Jakarta 12450 \\ ${ }^{2}$ Departemen Farmasi, Fakultas Kedokteran Universitas Pembangunan Nasional Veteran Jakarta 12450 \\ ${ }^{3}$ Departemen Ilmu Kesehatan Masyarakat-K3, Fakultas Kedokteran UPN Veteran Jakarta \\ 12450 \\ Email* : via.rifkia89@upnvj.ac.id
}

Riwayat artikel: Dikirim: 11/07/2020; Diterima: 25/08/2020, Diterbitkan: 27/12/2020

\begin{abstract}
Chronic Kidney Disesase (CKD) still has a very high prevalence in Indonesia. The management of End Stage Renal Disease (CKD Stage 5) is renal replacement therapy, one of them is hemodialysis therapy. Complications are often found in hemodialysis process. The most common complication is intradialytic hypertension. The pathophysiology itself is still unknown but there are many ways to manage intradialytic hypertension. One of them is antihypertensive drugs. The purpose of this research is to compare the blood pressure reduction between Amlodipine and Captopril for intradialytic patients. The dosages were $10 \mathrm{mg}$ Amlodipine and $25 \mathrm{mg}$ Captopril.This study used cross sectional method on hemodialysis patient with purposive sampling as the sampling method. Populations of this study were the hemodialytic outpatient at Bhayangkara Tk. I R. Said Sukanto Hospital. Data were primarily collected by measuring the blood pressure during to hemodialysis process. There were 73 patients gained as samples. The results of this research were the median value of Amlodipine's blood pressure reduction was $48 \mathrm{mmHg}$ and Captopril's was $47 \mathrm{mmHg}$. As the the calculation result, Amlodipine has the more significant blood pressure reduction than Captopril.
\end{abstract}

Keyword : Chronic Kidney Disease, Hemodialysis, Intradialytic Hypertension, Amlodipine, Captopril

\begin{abstract}
ABSTRAK
Gagal ginjal kronik (GGK) memiliki prevalensi yang cukup tinggi di Indonesia. Tatalaksana penyakit GGK stadium $\mathrm{V}$ adalah terapi pengganti ginjal, salah satunya adalah terapi hemodialisis. Beberapa komplikasi dapat disebabkan oleh proses hemodialisis. Komplikasi yang paling umum ditemukan adalah hipertensi intradialisis. Saat ini, hipertensi intradialisis masih belum diketahui patofisiologinya secara pasti, namun ada beberapa cara untuk mengatasi hipertensi intradialisis. Salah satunya adalah pemberian obat antihipertensi. Tujuan dari studi ini adalah untuk mengetahui perbandingan penurunan tekanan darah pasien hipertensi intradialisis dengan obat antihipertensi Amlodipin dan Kaptopril. Penelitian ini menggunakan desain potong lintang pada pasien hemodialisis dengan purposive sampling sebagai metode pengambilan sampel. Populasi dari studi ini adalah pasien rawat jalan hemodialisis di RS Bhayangkara Tk. I R. Said Sukanto. Data diambil secara primer melalui pengukuran tekanan darah pasien selama proses hemodialisis. Sebanyak 73 pasien didapatkan sebagai sampel. Hasil penelitian ini adalah Amlodipin memiliki penurunan tekanan darah sebesar $40 \mathrm{mmHg}$ dan Kaptopril sebesar $30 \mathrm{mmHg}$. Berdasarkan perhitungan tersebut, dapat disimpulkan bahwa Amlodipin memiliki penurunan tekanan darah yang lebih besar dibandingkan dengan Kaptopril.
\end{abstract}

Kata Kunci : Gagal Ginjal Kronik, Hemodialisis, Hipertensi Intradialisis, Amlodipin, Kaptopril 


\section{PENDAHULUAN}

Hipertensi adalah keadaan dimana terjadi peningkatan tekanan darah pada dinding arteri. Hipertensi merupakan faktor resiko utama terjadinya serangan jantung dan penyakit pembuluh darah lainnya. Pada umumnya, masyarakat awam sudah mengetahui hal ini. Namun, sebagian besar masyarakat belum menyadari bahwa hipertensi memiliki kaitan erat dengan kesehatan ginjal (Kemenkes, 2017). Hipertensi dapat menjadi pemicu terjadinya penyakit ginjal dan gagal ginjal. Sebaliknya, saat fungsi ginjal mengalami gangguan maka tekanan darah dapat meningkat dan menimbulkan hipertensi (Sherwood, 2013).

Gangguan ginjal yang dapat menimbulkan terjadinya hipertensi adalah gagal ginjal kronik. Hasil survei dari penelitian Dharmeizar (2007) menunjukan bahwa prevalensi gagal ginjal kronik (GGK) sebesar 29,1\% terjadi pada populasi dengan faktor risiko hipertensi, diabetes, atau proteinuria dan $0,8 \%$ diantaranya merupakan pasien GGK stadium $\mathrm{V}$ yang membutuhkan terapi. Selain transplantasi, jenis terapi pengganti ginjal lainnya adalah hemodialisis. Beberapa komplikasi yang dapat disebabkan oleh hemodialisis adalah diantaranya $70 \%$ pasien mengalami hipertensi, $40 \%$ pasien mengalami sakit kepala, 26\% pasien mengalami hipotensi, $18 \%$ mengalami kram otot, $12 \%$ pasien mengalami aritmia, $10 \%$ pasien mengalami sesak nafas dan $2 \%$ pasien mengalami demam hingga menggigil 2\% (Armiyati, 2013). Berdasarkan data tersebut, komplikasi berupa hipertensi merupakan komplikasi yang paling banyak ditemukan.

Hipertensi intradialisis adalah suatu kelainan berupa peningkatan tekanan darah sistolik selama atau pascadialisis dengan selisih systolic blood pressure (SBP) $\geq 10 \mathrm{mmHg}$ (Inrig et al., 2007). Komplikasi ini dapat terjadi akibat dari peningkatan curah jantung yang dimediasi oleh volume overload terutama pada pasien dengan berat badan berlebih dan dilatasi jantung. Selain hal tersebut beberapa penyebab lain dapat ditinjau dari proses ultrafiltrasi, faktor mekanik, dan stimulus hormonal selama hemodialisis yang dapat menyebabkan respon berupa sintesis faktor humoral oleh sel endotel yang berpengaruh terhadap homeostasis tekanan darah.

Beberapa komplikasi serius dapat terjadi akibat hipertensi intradialisis. Kondisi ini dapat menyebabkan kerusakan organ tubuh penting, seperti organ kardiovaskular, ginjal, paru-paru, maupun otak. Penelitian Inrig, et al. (2007) menyimpulkan bahwa faktor risiko yang dapat menyebabkan terjadinya hipertensi intradialisis adalah penggunaan obat antihipertensi sebelum atau selama menjalani proses hemodialisis.

Terapi obat antihipertensi digunakan pada pasien GGK untuk menurunkan tekanan darah. Selain itu terapi obat antihipertensi juga dapat memperlambat progresifitas penyakit. Terapi antihipertensi dan proses hemodialisis dalam kejadian hipertensi intradialisis terkadang berlawanan. Proses hemodialisis dapat meningkatkan klirens dari obat-obat tertentu yang dapat menurunkan kadar obat dalam darah. Penurunan kadar obat-obat antihipertensi selama proses hemodialisis dapat memicu terjadinya hipertensi intradialisis. American College of Cardiology/ American Heart Association menyebutkan bahwa, obat antihipertensi golongan Angiotensin Converting Enzyme Inhibitor (ACEI) yaitu kaptopril merupakan terapi lini pertama pada pengobatan hipertensi pada gagal ginjal kronik, namun terdapat penelitian lain yang menyatakan bahwa obat antihipertensi golongan Calcium Channel Blocker (CCB) yaitu amlodipin disebut efektif untuk menurunkan tekanan darah pasien hemodialisis atau hipertensi yang disebabkan oleh volume overload seperti yang terjadi pada pasien gagal ginjal kronik. (Inrig, 2011).

Berdasarkan latar belakang, peneliti tertarik untuk meneliti tentang penurunan tekanan darah pasien hipertensi dengan obat antihipertensi Kaptopril dan Amlodipin di RS Bhayangkara Tk. 1 R. Said Sukanto. 


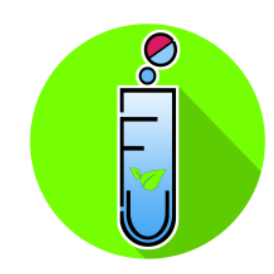

\section{METODE PENELITIAN}

\subsection{Desain Penelitian}

Jenis penelitian ini termasuk ke dalam penelitian kuantitatif. Penelitian ini menggunakan metode analitik observasional dengan pendekatan cross sectional, yaitu penelitian untuk perbandingan penurunan tekanan darah dengan obat antihipertensi Amlodipin dan Kaptopril. Desain cross sectional adalah suatu penelitian untuk mempelajari dinamika korelasi antara faktorfaktor risiko dengan efek, dengan cara pendekatan, observasi atau pengumpulan data sekaligus pada suatu saat (point time approach) (Notoadmodjo, 2012).

\subsection{Populasi dan Sampel}

Populasi penelitian ini adalah pasien hipertensi intradialisis yang memenuhi kriteria inklusi di RS Bhayangkara Tk. I R. Said Sukanto sebanyak 73 orang.

Kriteria pada penelitian kali ini yaitu pasien yang bersedia menjadi subjek penelitian, pasien dengan usia $>18$ tahun, pasien gagal ginjal kronis yang menjalani hemodialisis rutin $\geq 3$ bulan, dan pasien dengan peningkatan berat badan pasca dialisis $>4,8 \%$ dari berat badan kering di RS Bhayangkara Tk. I R. Said Sukanto.

\subsection{Pengambilan Sampel}

Teknik pengambilan sampel yang digunakan dalam penelitian ini termasuk dalam kategori non probability sampling yaitu teknik purposive sampling.

\subsection{Pengumpulan Data}

Data yang digunakan dalam penelitian ini merupakan data primer dan sekunder. Data primer didapatkan dari pengukuran tekanan darah yang diukur selama proses hemodialisis. Data sekunder penelitian ini didapatkan dari rekam medik yang digunakan untuk melihat obat antihipertensi yang digunakan di RS Bhayangkara Tk. I R. Said Sukanto.

\subsection{Prosedur Penelitian}

Sebanyak 73 pasien masuk ke dalam kriteria penelitian ini. Peneliti melakukan penjelasan tentang penelitian dan melakukan pengukuran tekanan darah pasien pada jam ke-3 hemodialisis.

\section{HASIL}

\section{Hasil Analisis Univariat \\ Karakteristik Sampel}

Karakteristik pasien hemodialisis meliputi usia, jenis kelamin, lama hemodialisis dan kenaikan berat badan kering. Karakteristik pasien dapat dilihat pada Tabel 1.

Tabel 1. Karakteristik Pasien

\begin{tabular}{clcc}
\hline No & \multicolumn{1}{c}{ Karakteristik } & N & \% \\
\hline $\mathbf{1}$ & Jenis Kelamin & & \\
& Laki-laki & 45 & 61,6 \\
& Perempuan & 28 & 38,4 \\
& Total & $\mathbf{7 3}$ & $\mathbf{1 0 0}$ \\
\hline $\mathbf{2}$ & Usia & & \\
& 17-25 tahun & 1 & 1,4 \\
& 26-35 tahun & 5 & 6,8 \\
& 36-45 tahun & 16 & 21,9 \\
& 46-55 tahun & 24 & 32,9 \\
& 56-65 tahun & 21 & 28,8 \\
& $\geq 66$ tahun & 6 & 8,2 \\
& Total & $\mathbf{7 3}$ & $\mathbf{1 0 0}$ \\
\hline $\mathbf{3}$ & Lama Hemodialisis & & \\
& 3-6 bulan & 18 & 24,7 \\
& 6-12 bulan & 32 & 43,8 \\
& $>12$ bulan & 23 & 32,5 \\
& Total & $\mathbf{7 3}$ & $\mathbf{1 0 0}$ \\
\hline $\mathbf{4}$ & Kenaikan $\quad$ Berat & & \\
& Badan (BB) Kering & & \\
& 4,8- 6 \% dari BB & 25 & 34,2 \\
& normal & & \\
& 6-8\% dari BB normal & 26 & 35,6 \\
& 8-10 \% dari BB & 14 & 19,2 \\
& normal & & \\
& $>10 \%$ T3 & & $\mathbf{1 0 0}$ \\
\hline Total & & \\
\hline
\end{tabular}

Sumber: Data Primer

Tabel 1 menunjukan bahwa sebagian besar pasien berjenis kelamin laki-laki yaitu sebanyak 45 pasien $(61,6 \%)$. Berdasarkan data usia, sebagian besar pasien pada penelitian ini termasuk kriteria masa lansia awal, yaitu berusia 46-55 tahun $(32,9 \%)$. Kemudian diikuti dengan 
kriteria usia terbanyak ke dua, masa lansia akhir, dengan rentang usia 56-65 tahun $(28,8 \%)$. Berdasarkan data lama hemodialisis, didapatkan mayoritas pasien sudah menjalani hemodialisis selama 6-12 bulan yaitu sebanyak 32 pasien. Pada tabel kenaikan berat badan kering, sebanyak 26 pasien mengalami kenaikan berat badan kering sebesar 6-8\%. Pengukuran berat badan kering dilakukan dengan mencatat berat badan setelah hemodialisis kemudian dilakukan pengurangan dengan berat badan sesaat sebelum hemodialisis berikutnya.

Jumlah pasien yang menggunakan obat antihipertensi Amlodipin dan Kaptopril dapat dilihat pada Tabel 2.

Tabel 2. Proporsi Penggunaan Obat Antihipertensi

\begin{tabular}{cccc}
\hline No. & $\begin{array}{c}\text { Obat } \\
\text { Antihipertensi }\end{array}$ & N & \% \\
\hline 1 & Amlodipin & 37 & 50,7 \\
2 & Kaptopril & 36 & 49,3 \\
& Total & $\mathbf{7 3}$ & $\mathbf{1 0 0}$ \\
\hline
\end{tabular}

Sumber: Data Primer, 2018

Pada Tabel 2 dapat dilihat bahwa jumlah pasien yang menggunakan Amlodipin adalah sebanyak 37 pasien dan Kaptopril adalah sebanyak 36 pasien.

\section{Hasil Analisis Bivariat}

Perhitungan bivariat digunakan untuk mengetahui rata-rata penurunan tekanan darah. Distribusi data penelitian tidak normal sehingga uji statistik yang digunakan adalah Uji MannWhitney.

Hasil perhitungan tersebut dapat dilihat pada Tabel 3.

Tabel 3. Rerata Penurunan Tekanan Darah

\begin{tabular}{ccc}
\hline No & Obat Antihipertensi & $\begin{array}{c}\text { Rerata } \\
\text { Penurunan } \\
\text { Tekanan Darah }\end{array}$ \\
\hline 1 & Amlodipin $10 \mathrm{mg}$ & $48 \mathrm{mmHg}$ \\
2 & Kaptopril $25 \mathrm{mg}$ & $47 \mathrm{mmHg}$ \\
\hline Sumb : Data Primer 2018 &
\end{tabular}

Sumber : Data Primer 2018

Berdasarkan Tabel 3 dapat dilihat bahwa nilai tengah penurunan tekanan darah sistolik dengan obat antihipertensi Amlodipin adalah sebesar $48 \mathrm{mmHg}$. Nilai tersebut didapatkan dari rata-rata selisih tekanan darah pada jam ke 1 dan jam ke 4 hemodialisis. Berdasarkan tabel diatas, Amlodipin memiliki rerata penurunan tekanan darah lebih signifikan yaitu sebesar $48 \mathrm{mmHg}$ jika dibandingkan dengan penurunan tekanan darah sistolik dengan Kaptopril yaitu sebesar 47 $\mathrm{mmHg}$.

\section{PEMBAHASAN}

Sebanyak 73 pasien yang memenuhi kriteria inklusi didapatkan sebagai sampel pada penelitian ini. Berdasarkan hasil pengolahan data, mayoritas pasien berjenis kelamin laki-laki. Pada penelitian Naysilla (2012), tidak ditemukan hubungan antara jenis kelamin terhadap kejadian hipertensi intradialisis. Hasil pengolahan data juga menunjukan kriteria usia mayoritas pasien adalah masa lansia awal dan masa lansia akhir. Hal ini dapat disebabkan karena adanya penurunan arterial compliance seiring dengan pertambahan usia. Hal ini sejalan dengan penelitian Assimon (2015) yang menyebutkan adanya hubungan antara usia tua dan kejadian hipertensi intradialisis. Selain itu adanya hubungan antara usia tua dengan hipertensi intradialitik juga disebutkan dalam penelitian Eftimovska-Otovic (2015). Pada kedua penelitian ini menyatakan bahwa usia tua cenderung tidak mendapatkan gizi yang cukup dan lebih banyak minum cairan sehingga tekanan darah dapat meningkat.

Patofisiologi dari hipertensi intradialisis sendiri masih belum diketahui secara pasti. Beberapa penelitian menyebutkan penyakit ini dapat disebabkan karena volume ekstraselular yang berlebihan, peningkatan aktivitas simpatis, aktivasi dari system renin-angiotensinaldosterone, disfungsi endotel, dan eliminasi dari obat-obatan antihipertensi akibat hemodialisis. Selain itu faktor eksternal seperti dialisat juga dapat menyebabkan hipertensi intradialisis. Dialisat dengan kadar natrium dan kalsium yang tinggi dapat menjadi penyebab kelainan ini. Obat-obatan seperti erythropoietin stimulating agent juga terbukti dapat menyebabkan kenaikan tekanan darah intradialisis. Penelitian Yuni Armiyati (2012) menyebutkan bahwa pada proses hemodialisis, insiden hipertensi 
intradialisis merupakan komplikasi yang lebih sering ditemukan dibandingkan dengan hipotensi intradialisis. Kejadian hipertensi intradialisis dapat disebabkan karena kelebihan cairan pradialisis. Kelebihan cairan memiliki peranan penting pada pasien hemodialisis. Selain itu, hal tersebut juga dapat disebabkan karena penarikan cairan menyebabkan turunnya volume cairan. Penurunan volume cairan dalam pembuluh darah dapat berakibat buruk pada perfusi ginjal. Perfusi ginjal yang turun dapat menstimulasi pelepasan renin dan menyebabkan hipertensi karena renin mengubah angiotensin I menjadi angiotensin II, menyebabkan vasokontriksi dan sekresi aldosterone. Mekanisme tersebut dapat meningkatkan tekanan darah saat hemodialisis. Hasil ini juga diperkuat oleh penelitian Inrig (2010) yang menyatakan bahwa kejadian hipertensi intradialisis sangat sering ditemukan dan memiliki resiko kardiovaskular yang lebih tinggi dibandingkan kejadian tekanan darah intradialisis lainnya.

Pada penelitian ini didapatkan peningkatan tekanan darah intradialisis terjadi pada jam ke tiga dari proses hemodialisis. Menurut Rahim \& Molony (2012) juga menyebutkan bahwa hipertensi intradialisis terjadi pada jam ke dua dan jam ke tiga selama proses hemodialisis. Pada penelitian ini tekanan darah diambil pada jam pertama dan jam terakhir hemodialisis. Hal ini bertujuan agar obat memiliki waktu untuk bekerja sesuai onsetnya sebelum diamati penurunannya. Lini pertama tatalaksana hipertensi intradialisis adalah obat antihipertensi golongan CCB dan ACEI. Jenis obat yang digunakan pada penelitian ini adalah golongan CCB khususnya Amlodipin dan ACEI khususnya Kaptopril. Alasan penggunaan obatobatan tersebut adalah karena kedua obat ini memiliki efek samping hipotensi yang tidak terlalu bermakna sehingga tidak mengganggu proses hemodialisis. Perbedaan fisiologis pasien juga mendasari pemilihan obat-obat ini. Selain itu kedua obat ini merupakan obat yang ditunjang oleh Badan Penyelenggara Jaminan Sosial (BPJS) di RS Bhayangkara Tk. I R. Said Sukanto sehingga kedua obat ini adalah obat yang paling umum diberikan pada pasien hipertensi intradialisis.

Hasil penelitian ini menunjukan bahwa sebanyak 37 pasien menggunakan obat Amlodipin dan sebanyak 36 pasien menggunakan Kaptopril. Dosis obat yang dipakai oleh rumah sakit penelitian adalah Amlodipin 10 mg dan Kaptopril 25 mg..

Amlodipin dan Kaptopril juga mempunyai kesamaan mekanisme kerja yaitu dengan mengurangi volume darah. Amlodipin mengurangi volume darah dengan menurunkan curah jantung sedangkan Kaptopril dengan menurunkan jumlah aldosteron yang berperan dalam reabsorbsi air dan natrium (Brunton, 2011). Bila ditinjau dari segi farmakokinetik, kedua obat ini memiliki karakteristik yang tidak jauh berbeda dalam pemberian intradialisis. Kaptopril dan Amlodipin diabsorbsi baik dengan pemberian per oral. Keduanya didistribusi ke seluruh tubuh dengan protein plasma. Kaptopril memiliki waktu paruh selama 4-12 jam dengan dosis $25 \mathrm{mg}$, sedangkan Amlodipin memiliki waktu paruh selama 12-20 jam dengan dosis 10 mg. Selain itu, Brunton (2011) juga menyebutkan bahwa Amlodipin dan Kaptopril mempunyai onset yang hampir sama dalam menurunkan tekanan darah yaitu Amlodipin 3060 menit dan Kaptopril 15-60 menit. Durasi kerja obat Kaptopril di dalam tubuh adalah selama 612 jam sedangkan Amlodipin adalah selama 20 jam. Hal tersebut menunjukan bahwa obat masih bekerja dalam masa hemodialisis (durasi selama 4 jam). Oleh karena hal-hal tersebut obat antihipertensi Kaptopril dan Amlodipin dapat digunakan pada penelitian ini untuk dibandingan penurunan tekanan darahnya.

Uji Mann Whitney memiliki syarat yaitu data penelitian harus homogen. Berdasarkan hasil uji normalitas dan uji homogenitas, Uji Mann Whitney dapat dilakukan untuk mengetahui apakah terdapat perbedaan penurunan tekanan darah dengan obat antihipertensi Amlodipin $10 \mathrm{mg}$ dan Kaptopril 25 mg. Hasil Uji Mann Whitney menunjukan $p$ value adalah sebesar $0,017(<0,05)$, sehingga dapat disimpulkan bahwa terdapat perbedaan penurunan tekanan darah pasien hipertensi intradialisis. Hal ini disebabkan karena terdapat 
perbedaan mekanisme kerja antara Amlodipin dan Kaptopril. Amlodipin sendiri merupakan obat antihipertensi golongan CCB dan termasuk kelompok dihidropiridin. Agen dihidropiridin merupakan direct vasodilator yang lebih selektif dibandingkan agen non-dihidropiridin. Selain itu agen dihidropiridine memiliki efek pada jantung yang lebih sedikit dibandingkan agen nondihidropiridin. Obat lainnya yaitu Kaptopril merupakan golongan obat antihipertensi ACEI. Golongan obat ini menghambat enzim peptidyl peptidase yang menghidrolisis Angiotensin I menjadi Angiotensin II (Katzung B, 2009). ACEI cukup sering digunakan dalam manajemen tekanan darah pasien hipertensi dengan gagal ginjal kronik karena dapat menghambat terjadinya proteinuria dan menstabilisasi kondisi ginjal walaupun obat golongan ini banyak hilang karena terdialisis. Penelitian Yen-chung Lin dkk (2017) menunjukan bahwa terdapat perbedaan efektivitas obat antihipertensi golongan CCB dan ACEI. Hal tersebut dapat terjadi karena obat-obat antihipertensi golongan CCB cenderung tidak ikut terdialisis sehingga memiliki efek yang lebih lama dibandingkan golongan ACEI. Setelah mengetahui terdapat perbedaan penurunan tekanan darah, dilakukan perhitungan deskriptif untuk mengetahui obat anthipertensi yang lebih signifikan dalam menurunkan tekanan darah pasien hipertensi intradialisis.

Uji statistika deskriptif dilakukan untuk mencari perbedaan penurunan tekanan darah pasien yang diberikan obat antihipertensi Amlodipin dan Kaptopril. Distribusi data penelitian ini adalah tidak normal sehingga nilai rata-rata (mean) tidak dapat digunakan. Nilai yang dapat digunakan untuk menentukan penurunan tekanan darah pada penelitian ini adalah nilai tengah (median) (Dahlan, 2013).

Pada penelitian ini, didapatkan rata-rata tekanan darah saat ditatalaksana dengan kedua obat adalah $170 \mathrm{mmHg}$ sehingga dapat disimpulkan bahwa baseline tekanan darah adalah seragam. Berdasarkan pengolahan data, didapatkan nilai tengah penurunan tekanan darah pasien dengan obat antihipertensi Amlodipin adalah sebesar $48 \mathrm{mmHg}$ dan nilai tengah penurunan tekanan darah pasien dengan obat antihipertensi Kaptopril adalah sebesar 47 mmHg. Hal ini menunjukan bahwa pasien dengan obat antihipertensi Amlodipin memiliki penurunan tekanan darah yang lebih besar jumlahnya daripada pasien dengan obat antihipertensi Kaptopril. Oleh karena itu, dapat disimpulkan bahwa penurunan tekanan darah pasien hipertensi intradialisis yang diberikan obat antihipertensi Amlodipin lebih signifikan daripada pasien yang diberikan obat antihipertensi Kaptopril. Hal ini sesuai dengan penelitian Yilmaz (2010) yang menyebutkan bahwa Amlodipin memiliki efektivitas lebih besar daripada Ramipril dalam menurunkan tekanan darah pasien hipertensi intradialisis. Pada penelitian tersebut, didapatkan penurunan tekanan darah sistolik pasien dengan Amlodipin adalah sebesar $26 \mathrm{mmHg}$ dan penurunan tekanan darah sistolik pasien dengan Ramipril adalah sebesar $24 \mathrm{mmHg}$. Hasil tersebut juga diperkuat oleh penelitian Inrig (2010). Penelitian ini menyatakan bahwa obat antihipertensi golongan CCB dapat secara efektif menurunkan tekanan darah pasien hipertensi karena volume overload seperti pada pasien hipertensi intradialisis sehingga dapat dijadikan lini pertama pengobatan hipertensi intradialisis. Hal tersebut disebabkan karena obat golongan CCB seperti Amlodipin tidak hanya bekerja pada otot polos pembuluh darah tapi juga bekerja pada otot-otot jantung. Amlodipin dapat menurunkan curah jantung yang dapat menurunkan volume darah sehingga dapat menurunkan tekanan darah. Selain itu penelitian itu menyatakan bahwa Amlodipin tidak ikut terdialisis oleh mesin hemodialisis sedangkan golongan ACEI seperti Kaptopril (kecuali Fosinopril) cenderung terdialisis sehingga efek obat dapat hilang seiring berjalannya proses hemodialisis. Penelitian Chazot \& Jean (2010) juga mengatakan bahwa obat antihipertensi golongan CCB lebih efektif pada situasi ini. Menurut penelitian tersebut, hipertensi intradialisis disebabkan oleh adanya penumpukan volume ekstraselular sehingga menurunkan curah jantung dengan Amlodipin dapat mengatasi hipertensi intradialisis.

American Heart Association (2017) memiliki pendapat yang berbeda yaitu lini 
DOI : https://doi.org/10.24843/JFU.2020.v09.i02.p03

pISSN: 2301-7716; eISSN: 2622-4607

Jurnal Farmasi Udayana, Vol 9, No 2, Tahun 2020, 83-90

penanganan pasien hipertensi intradialisis adalah Kaptopril. Hal ini dinyatakan dengan maksud untuk menghindari penurunan tekanan darah secara drastis yang dapat menyebabkan hipotensi karena Amlodipin. Penelitian lainnya oleh Yenchung Lin dkk (2017) juga menyimpulkan bahwa tidak terdapat perbedaan signifikan antara kelompok obat antihipertensi CCB dan ACEI. Pada studi meta-analisis tersebut, terdapat penelitian Shibasaki dkk (2005) yang menyebutkan rata-rata penurunan tekanan darah pasien dengan obat antihipertensi CCB adalah sebesar $10.7 \mathrm{mmHg}$ dan ACEI adalah sebesar $11.1 \mathrm{mmHg}$. Walaupun demikian, ACEI memiliki penurunan tekanan darah yang sedikit lebih besar dari CCB. Penelitian tersebut menyatakan bahwa hal ini terjadi karena ACEI mencegah penguraian dari bradykinin sehingga meningkatkan produksi nitrite oxide yang menyebabkan vasodilatasi. Selain itu, ACEI juga menghambat sistem renin-angiotensinaldosteron yang dapat menurunkan volume darah dengan menurunkan penyerapan natrium dan air melalui berkurangnya kadar aldosterone sedangkan, efek pengurangan volume darah melalui penurunan curah jantung oleh $\mathrm{CCB}$ masih kurang signifikan.

\section{KESIMPULAN}

Berdasarkan hasil penelitian dan pembahasan, dapat disimpulkan bahwa mayoritas pasien pada penelitian ini berjeniskelamin laki-laki.

Mayoritas pasien pada penelitian ini termasuk pada kriteria masa lansia awal. Mayoritas pasien sudah menjalani hemodialisis selama 6-12 bulan.

Mayoritas pasien memiliki kenaikan berat badan kering sebesar 6-8\%. Amlodipin $10 \mathrm{mg}$ diduga memiliki penurunan tekanan darah yang lebih signifikan yaitu sebesar $48 \mathrm{mmHg}$ dibandingkan Kaptopril 25 mg yaitu sebesar 47 mmHg.

\section{DAFTAR PUSTAKA}

1. Armiyati, Y. 2012. Hipotensi dan Hipertensi Intradialisis pada Pasien Chronic Kidney Disease ( CKD ) saat Menjalani
Hemodialisis. Seminar Hasil-Hasil Penelitian - LPPM UNIMUS: 126-135.

2. Assimon, M. M., Flythe, J. E. 2015. Intradialytic Blood Pressure Abnormalities: The Highs, The Lows and All That Lies between. American Journal of Nephrology: 42 (5): 337-350.

3. Brunton, L. L. 2011. Goodman \& Gillman's The Pharmacological Basis of Therapeutics $12^{\text {th }}$ edition. New York: McGraw Hill Medical.

4. Chazot, C., Jean, G. 2010. Intradialytic hypertension: It is time to act. Nephron Clinical Practice: 115 (3): 182-188.

5. Chou, K. J., Lee, P. T. 2006. Physiological Changes During Hemodialisis in Patients with Intradialysis Hypertension. Kidney Int: 69 (10): 1833-1838.

6. Dahlan, M. S. 2016. Langkah-Langkah Membuat Proposal Penelitian Bidang Kedokteran dan Kesehatan. Jakarta: CV Sagung Seto.

7. Dharmeizar, A. L., Nainggolan. G. 2007. Detection and Prevention of Chronic Kidney Disease in Indonesia Community Screening Study-A Preliminary Report. Asian Forum of CKD Initiative during the 50th Annual Meeting of the Japanese Society of Nephrology: 36.

8. Efimostika-Otovic, N. 2015. Clinical Characteristics of Patients With Intradialytic Hypertension. Mahy Masa: 64.

9. Indonesia, Kementrian Kesehatan Republik Indonesia. 2017. Situasi Penyakit Ginjal Kronis, Jakarta.

10. Inrig, J. K. 2011. Antihypertensive Agents in Hemodialytic Patients: A Current

11. Perspective. Semin-Dial NIH Public Access: 3.

12. Inrig, J. K., et all. 2007. Association of intradialytic blood pressure changes with hospitalization and mortality rates in prevalent ESRD patients. Kidney International: 71 (5): 454-461.

13. Inrig, J. K. 2010. Intradialytic Hypertension: A Less - Recognized Cardiovascular Complication of Hemodialisis. Am J Kidney Dis: 55 (3): 580-589. 
DOI : https://doi.org/10.24843/JFU.2020.v09.i02.p03

pISSN: 2301-7716; eISSN: 2622-4607

Jurnal Farmasi Udayana, Vol 9, No 2, Tahun 2020, 83-90

14. Katzung, B. G. 2009. Basic and Clinical Pharmacology $11^{\text {th }}$ ed. Boston: McGraw Hill.

15. Locatelli, F., Cavalli, A., Tucci, B. 2010. The Growing Problem of Intradialytic Hypertension. Nat Rev Nephrol: 6 (1): 4148.

16. Locatelli, F., Covic, A. 2004. Optimal Composition of The Dialysate, with Emphasis on its Influence on Blood Pressure. Nephrology Dialysis Transplantation: 19.

17. Malliara, M. 2007. The Management of Hypertension in Hemodialysis and CAPD Patients. Hippokratia: 11.

18. Naysilla, A. M. 2012. Faktor Risiko Hipertensi Intradialitik Pasien Penyakit Ginjal Kronik. Karya Tulis Ilmiah. Program
Sarjana Pendidikan Kedokteran Umum Universitas Diponegoro.

19. Nissenson \& Fine 2008, Handbook of Dialysis Therapy $4^{\text {th }}$ Edition, Saunders: Elsevier.

20. Rahim, N. A., Molony, D. 2012. Intradialytic Hypertension: An UnderRecognized Cardiovascular Risk Factor, What is the Evidence? Current Hypertension Reviews: 8: 282-290.

21. WHO. 1992. Prevention of cardiovascular disease, Occasional Paper (Royal College of General Practitioners): 58.

22. Yilmaz, R., et all. 2010. Impact of Amlodipine or Ramipril Treatment on Left Ventricular Mass and Carotid Intima Media Thickness in Nondiabetic Hemodialisis Patients. Renal Failure: 32 (8): 903-912. 